\title{
A clinical study on medication overuse headache in childhood and adolescence
}

\author{
F Piazza ${ }^{1}$, M Chiappedi ${ }^{2}$, E Maffioletti ${ }^{3}$, F Galli ${ }^{4 *}$, G Spada ${ }^{3}$, G Nappi ${ }^{4}$, U Balottin ${ }^{1}$ \\ From The European Headache and Migraine Trust International Congress \\ London, UK. 20-23 September 2012
}

\section{Introduction}

There are few studies on Medication Overuse Headache $(\mathrm{MOH})$ in children and no epidemiological studies on an Italian population. We evaluated the prevalence of $\mathrm{MOH}$ in patients referred to our Center in 2011.

\section{Methods}

We studied 118 patients looking for correlations between age of onset, sex, age at first contact, headache type, presence of Chronic Daily Headache (CDH), pain frequency, severity and presence of $\mathrm{MOH}$ (according to the revised criteria [1]) by Student's t test, Pearson's Chi Square and Mann-Whitney's test were used to analyze data.

\section{Results}

$44.9 \%$ of the sample had a diagnosis of $\mathrm{CDH}$. Among this group the prevalence of medication overuse was $20.8 \%$. After 2 months of drug withdrawal $45.4 \%$ of the patients reported a significant improvement. No significant correlation was found between the presence of $\mathrm{MOH}$ and age of onset, sex, age at first contact, headache type, pain frequency and severity.

\section{Conclusion}

About $1 / 5$ of children with $\mathrm{CDH}$ afferent to our Headache Unit are at high risk of worsening because of medication overuse. No previous studies showed a role for medication overuse in the etiopathogenesis of $\mathrm{CDH}$ in children and adolescents [2]. We suggest to keep in mind the possibility of medication overuse in children with headache and to investigate it carefully. Further studies are required to define a specific treatment protocol.

${ }^{4}$ Headache Science Centre of the IRCCS 'National Institute of Neurology C. Mondino' Foundation, Pavia, Italy

Full list of author information is available at the end of the article

\section{Author details}

'Child Neuropsychiatry Unit - IRCCS "C. Mondino" (Pavia), Italy. ${ }^{2}$ Don Carlo Gnocchi ONLUS Foundation - Milan, Italy. ${ }^{3}$ Child Neuropsychiatry, University of Pavia, Italy. ${ }^{4}$ Headache Science Centre of the IRCCS 'National Institute of Neurology C. Mondino' Foundation, Pavia, Italy.

Published: 21 February 2013

\section{References}

1. Olesen J, Bousser MG, Diener HC, Dodick D, First M, Goadsby PJ, Göbel H, Lainez MJ, Lance JW, Lipton RB, Nappi G, Sakai F, Schoenen J,

Silberstein SD, Steiner TJ: New appendix criteria open for a broader concept of chronic migraine. Cephalalgia 2006, 26(6):7412-746.

2. Galli F, Patron L, Russo PM, Bruni O, Ferini-Strambi L, Guidetti V: Chronic daily headache in childhood and adolescence: clinical aspects and a 4-year follow-up. Cephalalgia 2004, 24(10):850-858.

doi:10.1186/1129-2377-14-S1-P27

Cite this article as: Piazza et al: A clinical study on medication overuse headache in childhood and adolescence. The Journal of Headache and Pain 2013 14(Suppl 1):P27

\section{SpringerOpen ${ }^{\odot}$}

(C) 2013 Piazza et al; licensee Springer. This is an Open Access article distributed under the terms of the Creative Commons Attribution License (http://creativecommons.org/licenses/by/2.0), which permits unrestricted use, distribution, and reproduction in any medium, provided the original work is properly cited.
Submit your manuscript to a SpringerOpen ${ }^{\circ}$ journal and benefit from:

- Convenient online submission

- Rigorous peer review

- Immediate publication on acceptance

- Open access: articles freely available online

- High visibility within the field

- Retaining the copyright to your article

Submit your next manuscript at $\mathbf{s p r i n g e r o p e n . c o m ~}$ 